\title{
Administrasi Pengelolaan Zakat Dalam Pemberdayaan Umat
}

\author{
${ }^{1}$ Ii Sumantri \\ ${ }^{1}$ UIN Sunan Gunung Djati Bandung, Indonesia; iisumantri73@gmail.com
}

\begin{abstract}
Even though the term zakat has been widely known by the people of Indonesia with the largest Muslim population in the world, awareness of paying zakat seems to be not optimal. This is suspected by the problem of the administrator and the management, namely that in practice there are two attitudes of the zakat payer himself. This study aims to analyze the administration of zakat management in empowering the people. In conducting this research, a qualitative approach was used with this type of descriptive research. The results of this study indicate that there are at least three ways to improve the professional administration of zakat management so that it can have an impact on empowering people more optimally. This research can be concluded that the actual economic weakness of the Ummah lies not in the absence of potential, but the weakness in processing the economic potential towards being productive and also in processing the economic potential of the Muslim community, not having no Islamic institution, but the existing institutions have not yet been fully trusted.
\end{abstract}

Keywords: Islamic Administration, Public Policy, Civic Engagement, Well-Being, Zakat.

\section{Pendahuluan}

Kendatipun istilah zakat telah dikenal luas oleh warga suatu negara maupun mancanegara sejak berabad-abad lalu, namun persoalan di sekitarnya sampai sekarang masih tetap aktual untuk dibahas. Yang paling pokok dari persoalan itu adalah pengelola dan pengelolaannya. Dengan adanya persoalan ini bukan berarti masalah kesadaran membayar zakat dengan serta-merta tidak patut dioptimalkan. Sebab melalui bayaran saja, terlebih jika dihitung secara matematis, nampaknya umat Islam tidak harus terperosok di lembah kemelaratan, jika zakat dari padanya mampu ditarik semuanya. Apabila merujuk pada pusat data Badan Amil Zakat Nasional (BAZNAS), ditengarai bahwa Indonesia memiliki potensi zakat yang sangat besar, yaitu 217 triliun (Arif, 2018). Namun, nampaknya potensi zakat yang sangat besar tersebut masih jauh dari cukup, karena di tahun 2016 zakat yang berhasil dihimpun hanya bisa mencapai kurang dari 2\% (Baznas, 2016). Jika saja sepertiganya saja potensi zakat itu dapat ditarik, sebenarnya umat Islam khususnya di Indonesia akan mampu membiayai sarana-sarana umum umat Islam.

Atas dasar dugaan itulah patut dipersoalkan, bagaimana lembaga pengelola dan pengelolaannya yang sampai sekarang oleh banyak orang masih dipertanyakan atau belum mendapatkan kepercayaan secara penuh. Akibatnya walaupun pemerintah telah membentuk BAZNAS dibawah koordinasi Pemerintah baik pusat maupun daerah yang sebenarnya merupakan langkah maju, namun dalam praktiknya terjadi dua sikap dari pembayar zakat itu sendiri, yaitu di satu sisi umat Islam telah mengetahui bahwa dalam membayar zakat harus melalui lembaga yang ditunjuk BAZNAS atau melalui BAZNAS langsung. Tetapi pada sisi lain banyak yang tidak berkenan melalui lembaga ini karena ada semacam keraguan dalam proses pendistribusiannya. Pada faktanya, jika merujuk pada UU No. 23 Tahun 2011 Tentang 
Pengelolaan Zakat, maka belum diatur secara komprehensif mengenai standarisasi yang ideal dari proses pengumpulan, pengelolaan, dan pendistribusian zakat.

Walaupun sikap paradoks di atas cenderung berlebihan, tetapi seharusnya hal itu harus ditangkap sebagai suatu permasalahan yang mendorong tidak efektifnya pengelola dan pengelolaan zakat di tanah air. Sejarah membuktikan di masa Abu Bakar para muzaki pernah mogok enggan menyerahkan zakat kepada lembaga bentukan khalifah, hanya lantaran ketidakpercayaan terhadap do'a amilin. Pada sisi lain, ada harapan bahwa masalah ini harus diselesaikan lebih serius lagi, mengingat bagi umat Islam zakat merupakan sumber dana pemberdayaan umat yang sangat strategis. Dengan demikian, penelitian ini bertujuan untuk menganalisis konsep administrasi zakat dalam memberdayakan umat di Indonesia.

\section{Metode Penelitian}

Dalam melakukan penelitian ini, digunakan paradigma kualitatif yaitu dengan alur pemikiran induktif. Hal ini mengandung arti bahwa penelitian ini bermaksud untuk memotret dan menginterpretasikan fenomena lapangan dengan melibatkan metode yang bisa dipertanggung jawabkan. Penelitian ini juga bermaksud untuk mengeksplor lebih jauh tentang fenomena yang tidak dapat dikuantifikasikan atau dengan kata lain bersifat deskriptif atas objek yang memiliki karakteristik tertentu. Jenis penelitian ini tergolong pada jenis studi literatur, yang berarti bahwa penelitian ini tidak melakukan penelitian lapangan namun hanya mendasarkan pada sejumlah literatur yang sifatnya lapangan maupun kepustakaan. Oleh karenanya, sejumlah literatur dalam penelitian ini diperoleh dari skripsi, tesis, disertasi, artikel, jurnal, prosiding, dan lain sebagainya.

\section{Hasil dan Pembahasan}

\section{Konsep Pemberdayaan Zakat}

Ketika berbicara zakat, sebagai salah satu solusi untuk menyelesaikan problem kemiskinan, maka pertanyaan yang sering muncul dalam benak pikiran kita, apakah kita bisa dan bagaimana caranya agar problem ini bisa diselesaikan dengan baik. Untuk persoalan ini mungkin kita mengatakan bahwa tujuan umat Islam adalah mengoptimalkan pengelolaan zakat. Terdapat beberapa instrumen yang sangat penting dan harus dioptimalkan semaksimal mungkin dalam rangka menyelesaikan problem kemiskinan umat, yaitu peran lembaga pengelola Zakat, profesionalisme lembaga pengelola Zakat, dan peran pemerintah dan masyarakat. Signifikasi zakat tidak boleh diberlakukan semata-mata sebagai rukun Islam tetapi harus dilihat dalam hubungannya dengan efek sosial dan ekonomi, sebab muatan zakat adalah muatan sosial.

Tiga instrumen ini didasarkan atas fakta yang terjadi di lndonesia, bahwa masih banyak beberapa faktor yang menghambat, pertama eksistensi lembaga pengelola zakat sebelum kelahiran Undang-undang No. 33 Tahun 1999 tentang Pengelolaan Zakat, kedua profesionalisme lembaga pengelola zakat, ketiga mengenai kurangnya pendidikan mengenai zakat di masyarakat termasuk kurikulum mengenai zakat di lembaga pendidikan yang belum memenuhi standar kontemporer. Ketiga peran strategis itu bisa diuraikan sebagai berikut, yaitu 1) pertama, dapat diperjelas mengenai bentuk serta kedudukan hukum lembaga yang bertanggung jawab mengenai pengumpulan zakat setelah lahirnya Undang-undang maka jelas diketahui lembaga-lembaga tersebut adalah BAZNAS (bersifat Pemerintah) dan LAZIS, hal ini penting, karena jika tidak, maka lembaga-lembaga zakat tidak akan efektif dalam mengelola zakat, padahal masyarakat miskin sangat membutuhkan zakat, karena itu pemerintah wajib 
memperjelas status undang-undang pengelolaan zakat agar dapat menjadi pedoman dan sandaran bagi pengelola zakat sehingga tidak dianggap melanggar hukum zakat sebab dalam perspektif legalitas hukum, zakat memang lebih baik dikelola oleh pemerintah atau negara sebagaimana dibuktikan pada masa Nabi Muhammad SAW dan Khulafa al-Rasyiddin, artinya pemerintah harus bertanggung jawab dalam kesejahteraan masyarakat dan menjamin pelaksanaan keagamaan masyarakat.

2) Kedua, melakukan restrukturisasi dan revitalisasi lembaga-lembaga pengelola zakat baik BAZNAS maupun LAZ dengan cara memperbaiki kinerja dan manajemen yang lebih profesional sehingga mampu mendistribusikan dan mendayagunakan zakat sesuai dengan ketentuan Agama. 3) Ketiga, pemerintah harus gencar memberdayakan masyarakat melalui BAZNAS sebagai sumber pengumpul dana masyarakat sehingga BAZAS bisa mengimplemetasikan kebijakan pendistribusiannya kepada masyarakat melalui lembagalembaga sosial keagamaan, agar kebutuhan mustahiq masyarakat dapat terakomodir dengan baik dan dapat lebih memberdayakan lembaga-lembaga tersebut. Meminjam definisi Anang Arif Susanto bahwa Zakat adalah kebijakan alternatif anti kesenjangan dan anti kemiskinan dan proses pemberdayaannya harus terus dijalankan oleh berbagai pihak demi terciptanya masyarakat yang sejahtera.

\section{Strategi Pemberdayaan Umat}

Secara sederhana pemberdayaan umat dapat diartikan sebagai upaya membangkitkan potensi umat Islam ke arah yang lebih baik dalam kehidupan sosial, politik dan ekonominya. Zakat secara irnplementatif lebih erat berkaitan dengan pemberdayaan ekonomi. Adalah bukan sekedar isu, tetapi merupakan kenyataan yang sulit dipungkiri bahwa selama ini ekonomi umat Islam kurang menggembirakan, kalau tidak disebut memprihatinkan. Adalah "Aib sosial" yang perlu ditobatkan dengan membuat langkah-langkah strategis, ketika ada kenyataan bahwa umat Islam sebagai penduduk mayoritas bangsa ini justru minoritas dalam kekuatan ekonominya, dan malah terpinggirkan. Maka tak harus ditunda lagi tentang perlunya menggali "harta agama". Artinya harta bagi kekuatan umat Islam yang digali berdasarkan perintah Allah SWT. maupun berdasarkan petunjuk Rasullullah SAW. "Harta Agama" yang paling dekat adalah harta yang digali dari zakat. Sebagai kewajiban yang harus ditunaikan terutama bagi muslim yang telah memenuhi nishab.

Penggalian "harta agama" berupa zakat punya dua sisi yang menguntungkan. Yang tentu berbeda dengan penggalian harta di luar "harta agama" dalam prespektif Islam yang kadang merugikan salah satu pihak. Pertama, zakat mempunyai keuntungan bagi mereka yang menunaikan (membayarnya) berupa kebersihan jiwa dan kebersihan bathin (Q.S. 9: 103). Di samping Al-Qur'an menyebutnya sebagai ibadah kedua setelah shalat (QS. 2: 43). Kedua, Allah menjamin akan mengantinya dan malah akan mensukseskan bisnis muzakki yang bersangkutan. Sedangkan bagi mereka yang menerimanya pasti akan mendapat keuntungan dan merasa senang hati (QS. 9 :59) karena ia merasa mendapatkan pertolongan dari bahaya kelaparan dan kemelaratan berkepanjangan dan dalam kondisi ini akan terwujud keadilan sosial yang kita dambakan. Lebih jauh, seperti pernah diungkapkan Umar r.a: "Apabila kamu memberikan zakat, maka berikanlah sehingga orang-orang yang menerimanya memproleh kecukupan". Kecukupan merupakan keuntungan maksimal bagi para penerima zakat, ditengah para pemberi zakat yang mungkin hidup dalam kemewahan.

Dengan demikian, zakat memang tidak mungkin untuk mendongkrak terwujudnya pemerataan perolehan harta yang bersifat sama jumlahnya. Terlebih teori di luar Islam yang dalam teorinya mewujudkan persamaan sama rata sama rasa, sebenarnya hanyalah merupakan mimpi belaka, dan malah menentang kenyataan sunnatullah. Bukankah teori persamaan kaum 
sosialis dan komunis pada akhirnya hanya ibarat khayalan panjang bahkan abadi. Islam mengajarkan kepedulian dan keadilan dalam bermasyarakat dalam arti Islam memberikan petunjuk bahwa ditengah ancaman kemiskinan sekalipun harus ada rasa adil, yakni diupayakan terpenuhinya kebutuhan fisik minimum di tengah kemewahan. Islam mengajarkan, bahwa kemiskinan harus bisa diminimalisir, kalau tidak dihapuskan sama sekali; sebagai strategi bagi pemberdayaan ekonomi umat dan suatu bangsa pada umumnya.

\section{Mengoptimalkan Implementasi Pemberdayaan Umat Melalui Zakat}

Keberadaan BAZNAS di Indonesia, sekali lagi merupakan langkah maju yang patut dipertahankan, sekaligus jangan lupa untuk ditingkatkan kualitasnya. Peningkatan kualitas tersebut tampaknya jauh lebih penting dibanding dengan istilah mempertahankan, karena pada peningkatan mengandung makna perbaikan; Baik pada struktur kelembagaannya maupun fungsi lembaga itu sendiri. Dalam kaidah Ushul Fiqih disebutkan "dar ul mafasid aula min jalbil masholih dan Al-Muhafazhah 'ala al-qadim al-shalih wa al-akhdz bi al-jadid al-ashlah." Dua kaidah ushul fiqh ini mengandung makna bahwa jikalau ada dua hal yang saling berbenturan antara yang satu yaitu menghilangkan suatu kadaruratan dengan sesuatu yang membawa manfaat, maka terlebih dahulu memprioritaskan menghilangkan kedaruratan tersebut. Terkecuali apabila kedaruratan tersebut lebih rendah dibandingkan manfaat yang akan diperoleh.

Nampaknya menjadi sulit untuk dihindari, bahwa selama ini BAZNAS sering kali dikenai tuduhan yang kurang menyedapkan. Seperti tugas BAZNAS sebagai "amilin" oleh beberapa orang dipelesetkan menjadi "ambilin", zakat menjadi "jaket", fukara-masakin menjadi "fukara masa kini" dan lain sebagainya. Ungkapan yang tak menyedapkan seharusnya tak hanya dipahami bahwa ternyata ada beberapa orang yang tega melecehkan lembaga zakat, melecehkan para pengurus zakat dan penerima zakat. Kurang lebih tuduhan semacam itu mungkin disebabkan dari adanya keinginan agar BAZNAS lebih fungsional sebagaimana mestinya. Namun, karena ketidaktahuan ke mana keinginan itu harus disampaikan, maka ia membuat sindiran-sindiran yang bersifat publik-ekspose.

Dibalik tuduhan itu ada kritik tersebunyi, bahwa selama ini pengelola dan pendistribusian zakat patut lebih diefektifkan dan diefisienkan. Penyaluran zakat yang bersifat konsumtif, kurang transparan pendistribusiannya, dan pada umumnya kurang adanya pertanggung-jawaban publik (umat Islam) atau pertanggungjawaban hasil dan penggunaannya diantara kebanyakan umat Islam tidak mengetahuinya. Ketidakjelasan dan ketidaktahuan akibat kurang adanya transparansi itulah yang berdampak terhadap tuduhan, kritikan, bahkan keraguan terhadap keberadaan BAZNAS selama ini, yang pada gilirannya akan mengakibatkan malas dan enggan membayar zakat, dan atau para muzaki ingin menyalurkan sendiri. Karena itulah, selain hal-hal diatas patut mendapatkan pembenahan, juga patut direnungkan secara mendalam akan kokohnya tekad para pengelola agar dana zakat itu lebih konsisten (Istiqomah) digunakan sebesar-besarnya untuk kepentingan pemberdayaan umat Islam.

Lalu bagaimana nasib dana zakat? Mungkin persoalannya hanya "tidak terdengar" saja, padahal itu tetap digulirkan untuk kepentingan umat Islam. Dan kesadaran umat untuk berzakat sudah meningkat. Hanya sejauhmana dana itu dapat dirasakan. Inilah persoalan yang sangat unik dan sekaligus memerlukan upaya cerdik agar dana zakat dalam implementasi betul-betul dirasakan. Dalam kerangka inilah beberapa hal patut dipertimbangkan untuk masa depan.

Pertama, perlu adanya reformasi lembaga zakat yang lebih profesional, proporsional, amanah, dan bertanggung jawab keumatan (rakyat) serta bersifat mandiri. Bukan lembaga yang berbelit-belit, dan bukan lembaga yang para pengurusnya tidak dikenal oleh umat Islam. Secara konkrit, patut dipertimbangkan bahwa ormas Islam layak diberi kepercayaan, mengingat baik 
lembaganya (ormas Islam) maupun para pengurusnya tentu dikenal luas. Dengan demikian, kita berharap pengelola zakat baik secara kuantitas maupun secara kualitas akan meningkat. Kedua, dalam era krisis ekonomi dan era pemberdayaan ekonomi kerakyatan, jelas para pengusaha kecil dan mereka yang ingin melakukan usaha kecil-kecilan memerlukan modal. Dana zakat pun dapat dijadikan "dana bergulir" yang bersifat produktif (tidak konsumtif). Seperti termaktub dalam berbagai kitab fiqih. Di samping penyaluran dana zakat untuk "dana abadi" untuk kegiatan-kegiatan lembaga ke-Islaman (ormas Islam, lembaga-lembaga pendidikan sosial lainnya) yang sifatnya permanen. Hal ini penting, agar lembaga-lembaga keIslaman tidak tumbuh dalam kekuatan "tangan di bawah" terus menerus yang menghilangkan kemandiriannya. Dengan adanya "dana abadi", lembaga ke-Islaman akan mampu bersikap tanpa harus mengikuti irama kekuatan "tangan di atas" dalam segala halnya.

Ketiga, perlu dirumuskan "kekuatan politik" bagi pengumpulan dana zakat sebesarbesarnya. Dalam arti zakat terkumpul tidak seperti sedekah biasanya yang bersifat "siapa suka" dan kapan "dia suka". Mengapa pajak bisa dipungut dengan kekuatan politik dalam arti "dapat memaksa" sedangkan zakat tidak? Abu Bakar Shiddik pernah menggunakan kekuatan politiknya untuk memaksa mereka yang enggan membayar zakat, padahal ia mampu membayarnya. Di Indonesia, diduga banyak orang yang mampu membayar zakat, namun enggan mengeluarkannya. Di sini kekuatan politik harus bicara untuk menyadarkan mereka yang enggan membayar zakat. Dengan cara ini kita dapat membayangkan bahwa bangsa Indonesia sesungguhnya bisa membangun masyarakat yang mungkin dananya sangat besar dihasilkan dari zakat. Dan jika zakat dalam pengambilannya dari orang mampu dengan kekuatan politik, niscaya kita tak menjadi kekuatan "tangan di bawah" melainkan "tangan di atas".

Ada dua corak yang mempersepsikan zakat, pertama zakat dipandang sebagai institusi untuk mencapai keadilan sosial; sebagai mekanisme penekanan akumulasi modal pada kelompok kecil masyarakat. Lalu pertanyaan kita adalah apakah porsi 2,5\% sudah cukup adil atau sudah sesuai dengan spirit keadilan Islam untuk mengentaskan persoalan kemiskinan umat? Kedua, apakah zakat bisa dikatakan sebagai lembaga karitas, yang kaya harus memperhatikan yang tidak punya? Namum perlu kita ingat bahwa dalam konteks pendistribusian kekayaan harus dilakukan secara adil dan merata sehingga harta itu tidak hanya bergerak dikalangan orang-orang kaya semata, melainkan bisa dirasakan oleh orang-orang yang lemah secara ekonomi.

Zakat memiliki fungsi sosial sebagai mekanisme mencapai keadilan sosial, karena fungsinya, porsi zakat sebesar 2,5\% perlu dipertanyakan lagi dan didiskusikan kembali oleh kalangan ekonom Islam, kita bisa mengambil contoh yang berkaitan dengan ini. Apabila dalam satu wilayah, hampir seluruhnya penduduk hidup dibawah garis kemiskinan, apakah pengenaan Zakat 2,5\% kepada minoritas orang-orang kaya terasa tidak akan bisa memadai untuk menyelesaikan problem kemiskinan, maka solusi untuk menyelesaikan kemiskinan bisa dengan meningkatkan persentasi zakat yang awalnya 2,5\% menjadi $10 \%$ atau $20 \%$ tapi persentasi ini bisa dilegalkan melalui peraturan pemerintah jika pemerintah bersungguhsungguh untuk membantu orang-orang miskin keluar dari jebakan kemiskinan, akan tetapi persentasi $10 \%$ atau $20 \%$ ini tidak ditujukan untuk semua penghasilan dari setiap profesi melainkan profesi yang memudahkan datangnya rizki.

Ketika Amien Rais dengan ijtihadnya menemukan ketentuan 20\% untuk zakat profesi banyak orang mempertanyakan gagasannya dengan beberapa pertanyaan, dalilnya apa? bagaimana metode istinbatnya? Lalu Amien rais menjawab pendek: "Saya bukan ahli fiqh" Meminjam Istilah Emha Ainun Najib Bahwa "Diatas hukum formal ada moralitas, diatas moralitas ada cinta, diatas fiqh ada akhlak, diatas akhlak ada taqwa dan tawakkal. Sebab 
menurut kajian fiqh bahwa kita diperintahkan membayar zakat cukup 2,5\%, tetapi kalangan orang tasawuf yang didalamnya terkandung makna cinta mungkin kita harus membayar zakat $100 \%$, tentu saja pendapat Emha ini ditolak mentah-mentah, karena tidak ada kaidah cinta dalam kajian ushul fiqh.

\section{Simpulan}

Pada akhir uraian ini izinkan saya membuat penegasan bahwa sebenarnya kelemahan ekonomi umat bukan terletak pada ketiadaan potensi, melainkan keringnya mengolah potensi ekonomi kearah yang produktif. Juga dapat dikatakan bahwa dalam mengolah potensi ekonomi umat Islam bukan tidak punya lembaga keeislaman, melainkan lembaga yang ada belum sepenuhnya diberikan kepercayaan. Hal lainnya adalah umat Islam bukan tidak mempunyai kekuatan politik, melainkan kekuatan politik yang ada belum mampu menekan dan mendongkrak kekayaan umat yang terbenam di perut orang-orang kikir. Alangkah bangga dan kuatnya umat ini apabila "tiga rahasia" di atas terungkap dengan baik. Dan Pemerintah Republik Indonesia yang kita cintai ini akan merasa lebih puas apabila secara nyata potensi umat Islam tergali dan termanfaatkan, khususnya bagi umat Islam itu sendiri. Sebab dalam posisi umat Islam yang mayoritas, maka kemelaratan ekonomi umat Islam akan menjadi salah satu tolok ukur ketidak mampuan kita sendiri, rakyat dan pemerintahnya. Sebaliknya, kemajuan ekonomi umat Islam akan menjadi tolok ukur keberhasilan pemerintah dan rakyatnya. Karena itu, sudah barang tentu pemerintah akan mendukung dan mendorong atas kemauan umat Islam agar zakat dikelola lebih profesional, proporsional, transparan, dan tepat guna.

\section{Referensi}

Abdurahman, M. (1997). Islam Transformatif. Jakarta: Pustaka Firdaus.

Al-Baqiy, A., Fuad, M. (1981). Al-faadz Al-Qur'an Al-Karim. Daar al-Fikr li at-Thaba'ah wa an-Nasr wa at-Tauzii.

Al-Jaziri, A.R. (1978). Al-Fiqhu ala Mazahibi al-Arba'ah. Beirut: Daar Fikr.

Al-Mubarakfury., Syafiyyur-Rahman. (2002). Ar-Rahiqul Makhtum, Bahtsun fi Sirah Nabawiyyah ala Shahibiha Afdhalish-Shalati Was-Salam. Edisi Indonesia oleh Kathur Suwardi, Sirah Nabawiyyah. Jakarta: Pustaka Al-Kautsar.

Al-Qasimi, M.J. (1978). Mahsin at-Tawil. Beirut: Dar Fikr.

Arif, A. (2018). Problematika Zakat di Indonesia. Diperoleh dari Kompasiana.com ; https://www.kompasiana.com/ahmadarif2118/5b0e4981caf7db4e145dd854/problemati ka-zakat-diindonesia\#: :text=Menurut\%20Data\%20Pusat $\% 20$ Kajian\%20Strategis,adalah\%20sebe sar\%20Rp\%20217\%20triliun.\&text=Padahal\%20zakat\%20merupakan $\% 20$ suatu $\% 20 \mathrm{ke}$ wajiban,orang\%20yang\%20telah\%20mencapai\%20nisabnya.

Ash-Shiddieqy, T.M.H. (1993). Pedoman Zakat. Semarang: Pustaka Rizki Putra.

Badruzaman, A. (2009). Dari Teologi Menuju Aksi, Membela Yang lemah, Mengempur Kesenjangan. Yogyakarta: Pustaka Pelajar.

Faris, M.A.Q.A. (2003). Kajian Kritis Pendayagunaan Zakat. Terj. Agil Husen al-Munawwar. Semarang: Dina Utama Semarang. 
Hafipuddin, D. (2003). Dakwah Aktual. Jakarta: Gema Insani Press.

Hikmat, H. (2004). Strategi Pemberdayaan Masyarakat. Bandung: Humaniora Utama Press.

Idris, S. (1997). Gerakan Zakat dalam Pemberdayaan Ekonomi Umat. Jakarta: Citra Putra Bangsa.

Mangkuto, I.J. (2004). Zakat Sebagai Instrumen Kebijakan Fiskal. Jakarta: Republika.

Mughiyah, M. J. (1996). Fiqh Ja'fari. Terj. Abu Zainab AB. Jakarta: Lentera Hati.

Nawawi, I. (1994). Al-Majmu Syarh al-Muhazzab. Beirut: Daar Fikr.

Qardhawi, Y. (2001). Fiqh Zakat. Beirut: Muassah Risalah.

Qudamah, I. (1992). Al-Mughni. Beirut: Daar Kutub Ilmiah.

Rahardjo, M.D. (2003). Peran Zakat dalam Mengatasi Sosial Ekonomi. Jakarta: Republika.

Sasono, A., et al. (2002). Solusi Islam atas Problematika Umat. Jakarta: Gema Insani Press.

Susanto, A.A. (2003). Zakat Anti Kesenjangan dan Anti Kemiskinan. Yogyakarta: Universitas Gajah Mada.

Zahra, M.A. (1995). Zakat dalam Perspektif Sosial. Terj. Ali Zamawi. Pustaka Firdaus. 